\title{
Te Kai Paka-Anuta: Food in a Polynesian Outlier Society
}

Patrick V. Kirch

\section{(2) OpenEdition \\ 12 Journals}

\section{Electronic version}

URL: http://journals.openedition.org/jso/1404

DOI: $10.4000 /$ jso. 1404

ISSN: 1760-7256

\section{Publisher}

Société des océanistes

\section{Printed version}

Date of publication: 1 December 2002

Number of pages: 71-89

ISSN: 0300-953x

\section{Electronic reference}

Patrick V. Kirch, "Te Kai Paka-Anuta: Food in a Polynesian Outlier Society", Journal de la Société des Océanistes [Online], 114-115 | Année 2002, Online since 26 May 2008, connection on 22 March 2021. URL: http://journals.openedition.org/jso/1404 ; DOI: https://doi.org/10.4000/jso.1404

\section{(9) $(\mathcal{Q} \Theta \Theta$}

Journal de la société des océanistes est mis à disposition selon les termes de la Licence Creative Commons Attribution - Pas d'Utilisation Commerciale - Pas de Modification 4.0 International. 


\title{
Te Kai Paka-Anuta : Food in a Polynesian Outlier Society
}

par

\author{
Patrick V. KIRCH *
}

\section{RÉSUMÉ}

En reconnaissance aux contributions fécondes de $J$. Barrau à l'ethnographie et à la préhistoire de la nourriture en Océanie, cet article présente un compte rendu ethnographique sur l'alimentation d'une société polynésienne parmi les plus isolées et les plus traditionnelles: la minuscule île " outlier» de Anuta dans les Salomon orientales. Utilisant comme base une enquête menée en 1971, l'article réexamine le système économique sousjacent de production, stockage et préparation de la nourriture qui constitue la structure quotidienne (habitus) des abris-cuisines de Anuta. La culture matérielle de la cuisine, l'activité de l'abri-cuisine, les relations entre hommes et femmes dans la cuisine ainsi qu'une série de recettes concrètes sont abordées. De plus, l'article discute de la taxonomie traditionnelle des nourritures crues et préparées.

MotS-CLÉS : alimentation, ethnographie, abri-cuisine, Anuta, îles Salomon orientales, " outlier » polynésien.

\section{Introduction}

When serious ethnographic work - in the Malinowskian sense - began in Polynesia in the first few decades of the $20^{\text {th }}$ century, the priorities were widely agreed to be such rapidly changing aspects of culture as religion and belief,

\begin{abstract}
In recognition of Jacques Barrau's seminal contributions to the ethnography and prehistory of food in Oceania, this paper presents an ethnographic account of food in one of the most isolated and traditional of Polynesian societies: the tiny "Outlier " of Anuta, in the eastern Solomon Islands. Based on fieldwork carried out in 1971, the paper reviews the underlying economic system of food production, food storage, and the cooking processes which constitute the "structures of everyday life » (habitus) within Anutan oven-houses. The material culture of cooking, oven-house activity, gender relations within the cookhouse, and the range of actual recipes are discussed. In addition, the paper discusses the folk taxonomy of raw and prepared foods.
\end{abstract}

KEYWORDS : food, ethnography of food, oven house, Anuta, East Solomon, Polynesian Outlier.

kinship, and ritual. More prosaic aspects of culture - such as the procurement of food, and more particularly indigenous concepts and processes of cuisine - were largely accorded only passing treatment, perhaps because they were considered less interesting, or perhaps because they were thought to be less susceptible to

* Department of Anthropology and P. A. Hearst Museum of Anthropology, University of California, Berkeley. 
change. Moreover, one suspects an unstated colonialist bias that Polynesian cooking was unsophisticated and underdeveloped in comparison with classical European or Asian cuisines. The early $-20^{\text {th }}$ century " museum ethnographies " such as those of the Bishop Museum (to use Thomas' [1989] term) typically devote a few pages to the material culture of cooking and cookhouses (e.g., Hiroa, 1930), but rarely give any ethnographically "thick» description of cultural categories of food, or of the techniques and processes used to prepare foods.

A rare exception is Firth's (1936: 94-116) fairly detailed account of Tikopian food preparation, a section of We, The Tikopia curiously omitted in later reprint editions of this nowclassic work. In this paper - written in memory of Jacques Barrau - I consider the foodways and cuisine of the closely-related Polynesian Outlier society of Anuta, located some $112 \mathrm{~km}$ from Tikopia. The paper is based on original ethnographic fieldwork carried out on Anuta for two months in 1971, during which I was a member of the first anthropological expedition to visit the island ${ }^{1}$.

Jacques Barrau devoted much of his life to investigating and reporting on the ethnobotany and indigenous horticultural production systems of Oceania. Linked to his interest in crop plants and the environment was his concern with food processing and storage, revealed in more than one publication (e.g., Barrau, 1963, 1965 ; Barrau and Peeters, 1972). Although we were both born in the islands, I met Jacques Barrau only a few times, the first in his Noumea office at the Commission du Pacifique Sud, where he graciously received Yosiho Kondo and me in 1968, during our malacological expedition to the Loyalty Islands. Although I never had the opportunity to discuss with him in detail our mutual interest in the anthropology of food, I believe that he would have appreciated this modest addition to the ethnographic record of the remote and neglected Polynesian Outliers, which I present here in his memory.

\section{Anuta : The Island and its People}

Anuta must certainly rank as one of the smallest permanently occupied volcanic islands in the Pacific, with a land area of only 0.4 square kilometers, and a resident population (in 1971) of 177 persons. This population density of approximately 432 persons/square kilometer is amazingly high for an isolated population sustaining itself under a traditional subsistence economy, with no cash cropping or significant food imports ${ }^{2}$. The high density level is sustained through a remarkably intensive and complex food production system (Yen 1973), by exploitation of rich reef, benthic, and pelagic marine resources surrounding the island, and by buffering of periodic risk from cyclone and drought through the use of food preservation and storage.

As part of our 1971 project, I mapped the entire island using telescopic alidade and plane table at a scale of 1:750, plotting in all major garden features, dwellings, cookhouses, and other cultural features (see Kirch and Rosendahl 1973 : Fig. 1 for a reduced version of this map). Geomorphologically, Anuta may be subdivided into : (1) the low volcanic hill (maximum elevation $80 \mathrm{~m}$ asl), whose summit is cloaked with a mosaic of short-fallow, mulched gardens dominated by taro, manioc, and formerly also Dioscorea yams ; (2) the hillslopes which are utilized for tree crops such as breadfruit and betel palm; and, (3) an accretionary beach terrace of unconsolidated calcareous sands much of which is also under arboricultural production. Habitations are clustered in small hamlets arrayed along the southern coastline, while the cookhouses are situated inland of the dwellings, some cookhouses dispersed well into the arboricultural zone. The Anutans cognize their insular landscape in terms of several lexically-marked spatial divisions that roughly correspond to these geomorphic and production zones : (1) Te Maunga, the hill and its gardens ; (2) Te Roto Penua, literally " the middle land", which is the interior portion of the arboricultural zone, where the main $C y r$ -

1. Anuta, which is extremely isolated as well as diminutive, up through the 1970 s had extremely limited contacts with the outside world. The island had been visited for a few hours by the 1933 Templeton Crocker Expedition of the Bishop Museum (McGregor, 1934), which had collected a few objects of material culture. Raymond Firth had also visited the island for a single day, using the information collected to author a short description of the island and its people (Firth, 1954). Our 1971 expedition was a part of the Bishop Museum's 1970-1971 Eastern Solomon Islands Culture History Project, under the overall direction of Roger Green and Douglas Yen. Together with D. Yen, and P. Rosendahl, I spent the period from October 30 to December 22, 1971 on Anuta, carrying out archaeological and ethnographic work. The research was supported by NSF Grant GS-2077 to Bishop Museum, Honolulu.

2. In 1971 there was no evident importation of food stuffs to the island, no trade store, nor was there any exportation of copra or other products. A few Anutans did work from time-to-time in the Russell Islands on the copra plantations, and when they returned brought with them such Western material items as cloth, small kerosene lanterns, metal kettles which they used to hold drinking water, metal fishhooks, and so forth. 


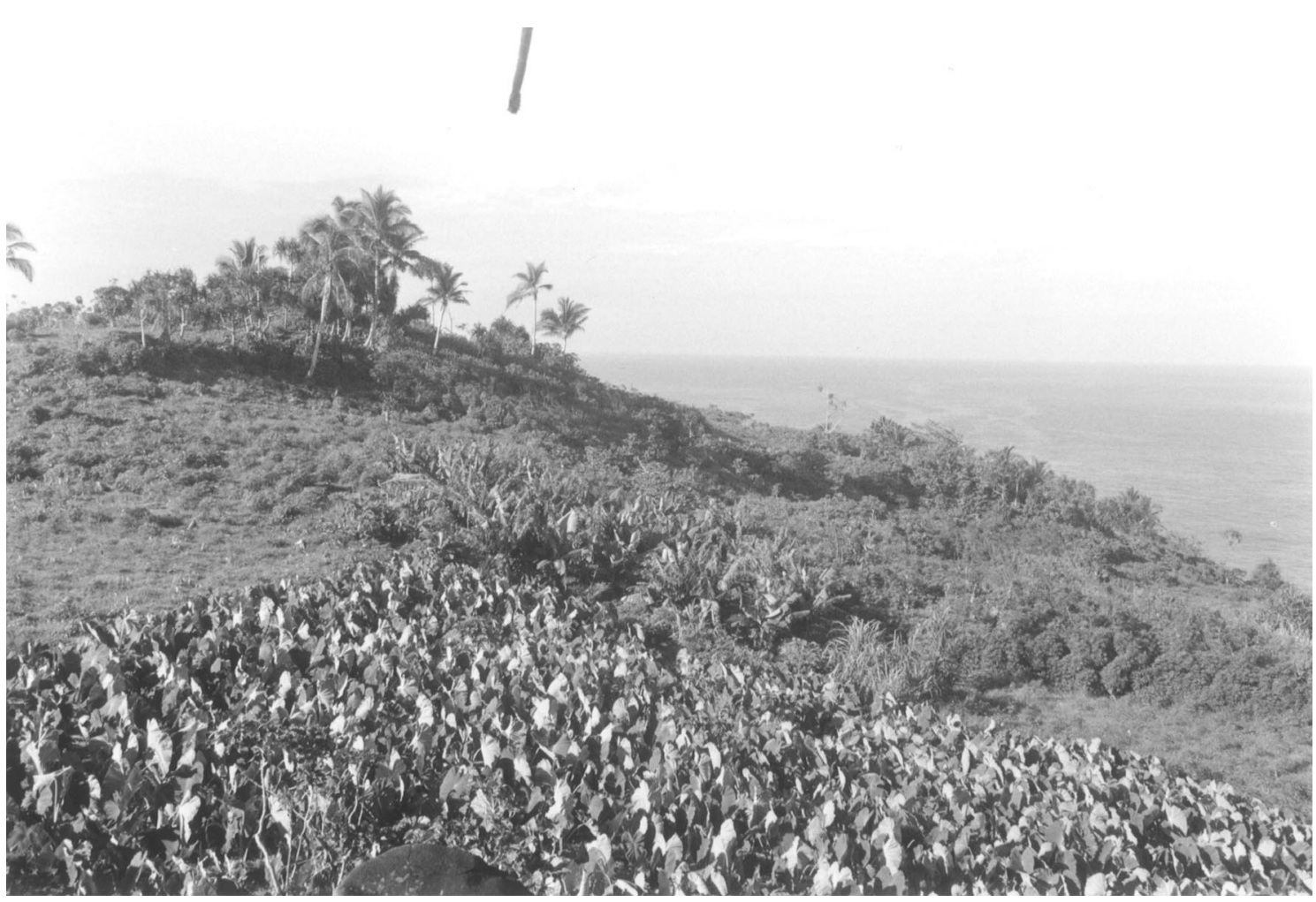

FIG. 1. - The intensive hill gardens with a taro garden in the foreground.

tosperma pits are situated; and (3) Te Aropi Penua, the seaward part of the coastal terrace where the habitations are concentrated. Other landscape divisions mark the steep cliffs on the northern side (Te Tua Penua), the eastern part of the island (Te Tu Tereva), and the western area where the island's only permanent freshwater source (a small seep) is situated (Te Uo Vai).

Archaeological evidence (Kirch and Rosendahl 1973, 1976) reveals that Anuta was first occupied around 900 B.C., by a population which used plainware pottery and other artifacts placing it within the broader Lapita cultural complex (Kirch, 1997). There is some evidence for an occupation hiatus (Kirch, 1982), probably related to a devastating cyclone event, after which the island was recolonized both by natural fauna such as seabirds (Steadman et al., 1990), and by humans. Within the historic period, the Anutan population both culturally and linguistically has comprised what could be considered a variant of the well-documented Tikopia culture and language (Firth, 1936). Anutans and Tikopians have close social ties, with intermarriage between the islands. Their languages, both part of an as-yet unclearly defined "Futunic" subgroup of Nuclear Polynesian languages (Marck, 2000), are mutually intelligible despite some phonological and other distinctions (Feinberg, 1977) ${ }^{3}$.

Socially the island's people are segmented into four named descent groups or kainanga: the Kainanga i Mua, Kainanga i Muri, Kainanga i Pangatau, and Kainanga i Rotomua (Feinberg, 1981). Two hereditary chiefs (ariki) and their retainers or maru form the overt political leadership. The primary domestic unit, the patongia, is best conceptualized as a "house » in the sense of Lévi-Strauss' sociétés à maison, or « house societies » (Lévi-Strauss, 1982); that is, the patongia comprises a group of persons who affiliate to a named residence, which also carries rights to associated garden lands, canoes, and other property. As has been increasingly recognized in Austronesian-speaking societies, the " house » is one of the most pervasive aspects of the longue durée of social structures (Fox, ed., 1993 ; Kirch, 1996, 2000 ; Kirch and Green, 2001). From the viewpoint of food - both its production and consumption - the patongia is

3. Pawley (1967) originally lumped all of the Polynesian Outlier languages into a Samoic-Outlier subgroup, which Marck (2000) abandoned in favor of an Ellicean Outlier group and the « Futunic » group. The latter includes Anutan, Tikopian, Pileni, the Polynesian Outliers in Vanuatu, East Futunan, East Uvean, and Pukapukan. 
the operative social unit. As Feinberg writes, « it is said that members of a patongia 'eat together' " and while this may in some cases be contravened in everyday practice, it is adhered to on major ceremonial occasions and feasts. " At such times, all members of a single patongia sit together on a common mat and eat from a common basket » (Feinberg, $1981:$ 74).

\section{Anutan Food Production}

Jacques Barrau $(1961,1965)$ definitively circumscribed the Oceanic crop plant complex, with its mix of field crops dominated by the ritually-marked taro (Colocasia esculenta) and yams (Dioscorea alata and related species), each of these the focus of respectively wet and dry methods of intensification (Kirch, 1994) ; its roster of arboricultural crops including breadfruit (Artocarpus altilis), sago (Metroxylon spp.), coconut (Cocos nucifera) and many others, in the southwestern Pacific often forming complex « orchard garden » systems; and, a diversity of other edible, medicinal, psychoactive, or other economic crops. A large number of these, such as the giant Cyrtosperma chamissonis aroid which the Anutans grow in large pits dug to tap the Ghyben-Herzberg fresh-water lens, or the Metroxylon sago palms which surround these pits, were domesticated within what Barrau termed the "foyer Indo-Pacifique» of ancient plant domestication (Barrau, 1965). Barrau would have marveled at the extensive array of no less than 37 Oceanic and historically-introduced crops which make up the complex vegetal world of the Anutans (Table 1), tightly integrated in a landscape of which there is barely a square meter not under cultural management.

Yen (1973) described the Anutan agricultural system based on our 1971 fieldwork, and here I offer a brief synopsis from the point of view of food production. From the ethnobotanical perspective, six discrete cropping zones may be distinguished, as summarized in Table 2. Zones I, III, and V, all situated on the low-lying calcareous terrace, are all dominated by arboricultural production, while Zone IV is a mix of the giant aroid Cyrtosperma grown in artificial pits (rotopue) under the shade of overarching Metroxylon palms. Zones II and VI are devoted to field crops, with sweet potato and tobacco restricted to the house gardens of Zone I. The most significant food production zone, in terms of both areal extent and yield, is Zone VI, the hill gardens which yield the bulk of the starch staples which are at the core of the Anutan diet (Yen 1973, table 5).
Whereas the arboricultural production zones mimic the multi-storey structure of a tropical rainforest (see Kirch and Yen, $1982: 63$ ), and require relatively low labor inputs to maintain, the hill gardens are highly labor intensive and artificial (Fig. 1). They consist of a mosaic grid of rectangular plots, their boundaries in many cases separated by stone-faced terraces, in which taro and manoic (formerly yams) are cultivated in a short-fallow rotation. The intensity of this field system is quite remarkable, and Yen notes that « on the undulating plateau, the rotation in individual fields is a continuous planting cycle of taro-manioc-taro without a significant fallow period » (1973: 125). Critical to the continual operation of this system is a constant input of mulch (Yen 1973, Fig. 6a), which serves both for moisture retention and for nutrient input. The use of grasses and herbs obtained from the halophytic strand zone probably assures a continual input of phosphorus, which may also be derived from the fine aerosol mist of seawater which blankets the island due to continual swell surges against the northern cliff.

The Anutuan orchard and field gardens yield a diverse array of vegetal foodstuffs, including the main starch staples (taro, manioc, Cyrtosperma, yams, sago), seasonally important starchy fruit (breadfruit, bananas), non-farinaceous fruit (e.g., Burckella, Spondias, Barringtonia), emollients (coconut, Cordyline), and famine and/or medicinal plants (e.g., Morinda). It is the starches which dominate Anutan cuisine, however, with seasonal fruit providing some variance in an otherwise repetitive diet.

The work of harvesting food crops is done by both men and women, although in our experience the burdensome task of transporting taro and manioc tubers from the hill gardens to the oven houses was exclusively performed by women and girls. Tubers or loads of fruit are generally carried in large woven baskets of coconut fronds (popora), strapped to the woman's back by means of two crossed strips of barkcloth. Anutans use four different words to differentiate the gathering and harvesting of vegetal foods :

$\begin{array}{lll}\text { Gather } & \text { Harvest } & \\ & \text { ranga } & \text { Root crops } \\ \text { paki } & \text { tori } & \text { Tree crops } \\ & \text { uui } & \text { Betel nut }\end{array}$

The general term paki refers to gathering any above-ground foodstuffs, while ranga is specific to the pulling and harvesting of tubers, and tori in contrast applies to tree crops such as breadfruit. The harvesting of betelnut, the stimulant so important to everyday social activities, has its own particular term, uui. 
TABLE 1

The Roster of Anutan Crop Plants

\begin{tabular}{|c|c|c|c|c|c|c|}
\hline $\begin{array}{l}\text { Anutan } \\
\text { Name }\end{array}$ & Botanical Name & English Name & $\begin{array}{l}\text { Crop } \\
\text { Type }^{1}\end{array}$ & $\mathrm{Use}^{2}$ & $\begin{array}{l}\text { Cropping- } \\
\text { Zone }^{3}\end{array}$ & $\operatorname{Age}^{4}$ \\
\hline Ango & Cucurma longa & Turmeric & $\mathrm{O}$ & $\mathrm{M}$ & $\mathrm{V}$ & I \\
\hline Atameri & Citrullus sp. & Watermelon & NF & NS & II & $\mathrm{H}$ \\
\hline$I p i$ & Inocarpus fagiferus & Polynesian chestnut & $\mathrm{FF}$ & NS & III & $\mathrm{I}$ \\
\hline Kapika & Eugenia malaccensis & Malay apple & NF & NS & III & I \\
\hline Kapingatara & Alocasia macrorrhiza & Elephant ear taro & FT & Ss & III, IV & I \\
\hline Kauariki & Terminalia catappa & Beach almond & $\mathrm{NF}$ & NS & III & I \\
\hline Kaura & Areca catechu & Betel nut palm & $\mathrm{O}$ & $\mathrm{N}$ & $\mathrm{V}$ & I \\
\hline Manioka & Manihot dulcis & Manioc & FT & MS & II, VI & $\mathrm{H}$ \\
\hline Mami & Antiaris toxicaria & & $\mathrm{O}$ & $\mathrm{B}$ & III & $\mathrm{I}$ \\
\hline Maoa & Tacca leontopetaloides & Polynesian arrowroot & FT & Ss & I & I \\
\hline $\mathrm{Mei}$ & Artocarpus altilis & Breadfruit & $\mathrm{FF}$ & MS & $\mathrm{V}$ & I \\
\hline Naporo & Carica papaya & Papaya & $\mathrm{NF}$ & NS & II & $\mathrm{H}$ \\
\hline Natu & Burckella obovata & & NF & NS & III & I \\
\hline Niu & Cocos nucifera & Coconut palm & $\mathrm{NF}$ & Ss, E & I, II & I \\
\hline Nonu & Morinda citrifolia & & $\mathrm{NF}$ & $\mathrm{M}$ & VI & I \\
\hline Ota & Metroxylon salomonense & Sago palm & FP & MS & IV & I \\
\hline Paka & Nicotiana tabacum & Tobacco & $\mathrm{O}$ & $\mathrm{N}$ & II, VI & $\mathrm{H}$ \\
\hline $\begin{array}{l}\text { Papakapa- } \\
\text { palangi }\end{array}$ & Ananas comosus & Pineapple & $\mathrm{NF}$ & NS & VI & $\mathrm{H}$ \\
\hline Pita & Piper betel & Betel leaf pepper vine & $\mathrm{O}$ & $\mathrm{N}$ & $\mathrm{V}$ & I \\
\hline Pukovai & Cordia subcordata & Tree with edible leaves & $\mathrm{O}$ & NS & I & I \\
\hline Puraka & Cyrtosperma chamissonis & Giant swamp taro & FT & MS & IV & I \\
\hline Putete & Ipomoea batatas & Sweet potato & FT & NS & II & $\mathrm{H}$ \\
\hline Puti & Musa hybrids & Bananas & FF & MS & II, VI & I \\
\hline Rabauro & Xanthosoma sagittifolia & South American taro & FT & Ss & III & $\mathrm{H}$ \\
\hline Taro & Colocasia esculenta & Taro & FT & MS & II, VI & $\mathrm{I}$ \\
\hline Taulo & Dioscorea sp. & Yam sp. & FT & Ss & III & $\mathrm{I}$ \\
\hline Taumako & Dioscorea esculenta variety & Lesser yam & FT & Ss & III, VI & I \\
\hline Taura & $\begin{array}{ll}\begin{array}{l}\text { Dioscorea } \\
\text { variety }\end{array} & \text { nummularia } \\
\end{array}$ & Yam leaves & $\mathrm{O}$ & NS & II, VI & $\mathrm{H}$ \\
\hline$T i$ & Cordyline fruticosum & $\mathrm{Ti}$ & FT & Ss & III & I \\
\hline To & Saccaharum officinarium & Sugar cane & $\mathrm{O}$ & $\begin{array}{l}\mathrm{N} \\
\mathrm{S}\end{array}$ & II, VI & I \\
\hline Upi & Dioscerea alata & Greater yam & FT & $\begin{array}{l}\mathrm{M} \\
\mathrm{S}\end{array}$ & VI & I \\
\hline Uporoi & $\begin{array}{l}\text { Dioscerea } \\
\text { nummularia variety }\end{array}$ & Yam & FT & Ss & III & $\mathrm{I}$ \\
\hline Upure & Dioscorea esculenta & Lesser yam & FT & $\begin{array}{l}\mathrm{M} \\
\mathrm{S}\end{array}$ & VI & I \\
\hline Varu & $\begin{array}{l}\text { Abelmoschus } \\
\text { moschantes }\end{array}$ & $\begin{array}{l}\text { Shrub with } \\
\text { edible leaves }\end{array}$ & $\mathrm{O}$ & $\begin{array}{l}\mathrm{N} \\
\mathrm{S}\end{array}$ & II, VI & $\mathrm{H}$ \\
\hline Vere & Barringtonia procera & Nut tree & $\mathrm{NF}$ & NS & III & I \\
\hline$V i i$ & Spondias dulcis & Vi apple & $\mathrm{NF}$ & NS & III & I \\
\hline$V o i$ & Dioscorea bulbifera & Bitter yam & FT & Ss & III, V & I \\
\hline
\end{tabular}

1. Crop type abbreviations : FP, farinaceous palm ; FT, farinaceous tuber or corm ; FF, farinaceous fruit ; NF, nonfarinaceous fruit ; $\mathrm{O}$, other.

2. Use abbreviations : MS, major staple ; Ss, secondary staple; NS, nonstaple food ; N, narcotic or psychoactive ; E, emollient ; B, barkcloth ; M, medicinal.

3. See Table 2 for definition of cropping zones.

4. Age of introduction abbreviations : I, indigenous, prehistoric introduction ; H, historic-period introduction. 
TABLE 2

Cropping Zones

\begin{tabular}{|l|l|l|r|}
\hline \multicolumn{1}{|c|}{ Zone } & \multicolumn{1}{|c|}{ Location and Soil } & \multicolumn{1}{c|}{ Dominant Crops } & \multicolumn{1}{c|}{$\begin{array}{c}\text { Area } \\
\text { (hectares) }\end{array}$} \\
\hline $\begin{array}{l}\text { I. Strand } \\
\text { Belt }\end{array}$ & $\begin{array}{l}\text { Immediate coastal zone; } \\
\text { calcareous sands; } \\
\text { halophytic }\end{array}$ & $\begin{array}{l}\text { Cocos nucifera } \\
\text { Pandanus tectorius }\end{array}$ & 5.9 \\
\hline $\begin{array}{l}\text { II. House } \\
\text { Gardens }\end{array}$ & $\begin{array}{l}\text { Coastal terrace; } \\
\text { calcareous soil enriched } \\
\text { by cultural detritus }\end{array}$ & $\begin{array}{l}\text { Colocasia esculenta } \\
\text { Manihot dulcis } \\
\text { Ipomea batatas } \\
\text { Musa } \text { (Eumusa } \text { hybrids }\end{array}$ & 3.12 \\
\hline $\begin{array}{l}\text { III. Antiaris } \\
\text { Forest }\end{array}$ & $\begin{array}{l}\text { Coastal terrace; } \\
\text { organic soil on calcareous sands }\end{array}$ & $\begin{array}{l}\text { Antiaris toxicaria } \\
\text { Dioscorea nummularia } \\
\text { Alocasia macrorrhiza } \\
\text { Inocarpus fagiferus } \\
\text { Spondias dulcis }\end{array}$ \\
\hline $\begin{array}{l}\text { IV. } \\
\text { Cyrtosperma } \\
\text { Zone }\end{array}$ & $\begin{array}{l}\text { Coastal terrace near base } \\
\text { of the hillslope; clay soils } \\
\text { over calcareous sands }\end{array}$ & $\begin{array}{l}\text { Cyrtosperma chamissonis } \\
\text { Metroxylon salomonense } \\
\text { Burckella obovata }\end{array}$ & 5.7 \\
\hline $\begin{array}{l}\text { V. Hillslope } \\
\text { Orchards }\end{array}$ & Colluvial soil & $\begin{array}{l}\text { Artocarpus altilis } \\
\text { Areca catechu } \\
\text { Piper betel }\end{array}$ & 3.16 \\
\hline $\begin{array}{l}\text { VI. Hill } \\
\text { Gardens }\end{array}$ & $\begin{array}{l}\text { Top of volcanic hill, } \\
\text { clay soils }\end{array}$ & $\begin{array}{l}\text { Colocasia esculenta } \\
\text { Manihot dulcis } \\
\text { Musa } \text { (Eumusa } \text { hydrids } \\
\text { Morinda citrifolia }\end{array}$ & \\
\hline
\end{tabular}

Lacking domestic pigs or dogs, and with the taking of nesting seabirds being a very limited activity, the main source of protein in the Anutan diet is the ocean, which yields a variety of invertebrates, fishes, turtles, and other marine foods. Fish are taken by a variety of strategies, including angling with hook and line, trolling or bottom fishing from canoes, netting of various kinds on the fringing reef platform, flying-fish netting from canoes, spearing, communal fish drives using a stone fish weir on the reef, and communal surrounds and netting without the use of weirs.

Much shellfish gathering, spearing, netting, and hook-and-line fishing is done by individuals or small groups on a daily basis. However, when fish in quantity are required for community-wide feasts or ceremonial occasions, larger groups are mobilized. We witnessed both surround and weir fishing on December 3, 1971, in preparation for a feast. Nearly 100 people were involved in these activities, driving a school of ume (Naso sp.) into the weir (Fig. 2), yielding an estimated $80-90 \mathrm{~kg}$ of fish over about 2 hours. Shortly later a group of about 30 people surrounded a school of nanue and caught another 40-50 kg in less than half an hour. When fish are to be consumed communally, they are frequently cooked in a particularly large earth oven (umu) situated in the lee of a large outcrop near the canoe landing
(Te Ava). Canoe fishing is carried out whenever the seas permit (getting canoes on and off the island through the tiny pass can be lifethreatening when the seas are high). Fish are caught by trolling while under sail, but also by bottom-fishing, as there are extensive areas of relatively shallow bottom surrounding the island for some distance.

Other sources of food include chickens (which are free-ranging on the island), sea birds, and bird eggs. Chickens (kio) were said to be a recent introduction, and are all held to be the property of the Ariki i Mua ; they seem only to be eaten at feasts. Seabirds (especially frigates and terns) and their eggs are eaten. A few of these drive from nesting populations on the island, but many more are taken during canoe voyages to Fatutaka, an uninhabited rocky islet or pinnacle some $32 \mathrm{~km}$ to the southeast. When the winds are favorable, the Anutans sail to Fatutaka to gorge themselves on eggs and to take seabirds back to Anuta to eat.

\section{Food Storage}

With its high population density, Anuta is highly susceptible to various sorts of environmental hazards, especially drought and cyclones, both of which can devastate the island's terres 


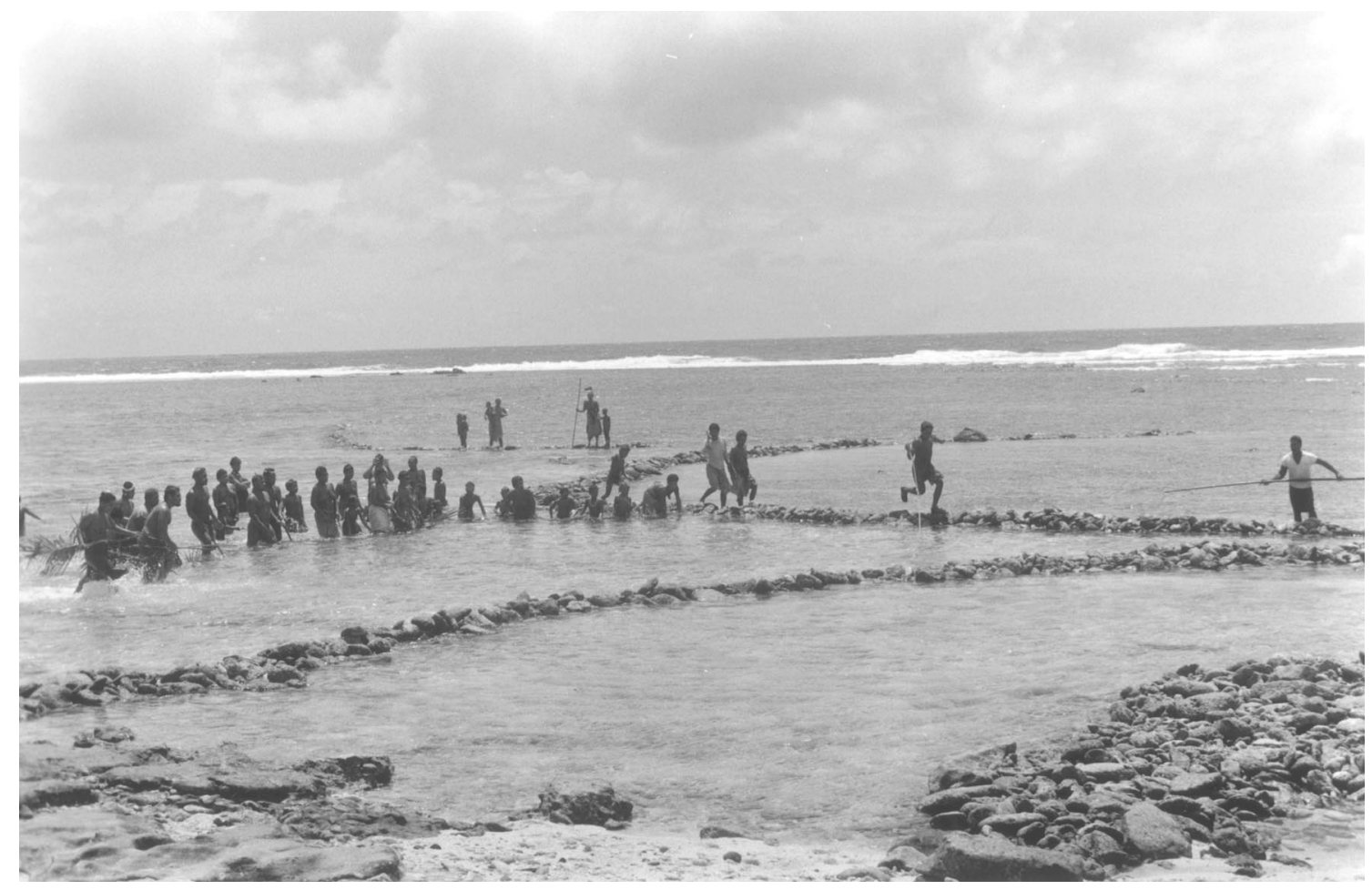

FIG. 2. - Driving a school of fish into the stone weir on the reef.

trial production system, putting the small human population at serious risk. Both droughts and cyclones figure as themes in Anutan oral traditions (Feinberg, 1998), further demonstrating the importance that Anutan people accord them. The main strategy for «buffering" against such predictable but stochasticallyrecurring hazards is significant storage of fermented, uncooked staple starch, known as ma. $M a$ (or masi) storage was a formerly-widespread technique throughout most of tropical Polynesia (Cox, 1980 ; Yen, 1975 ; Kirch, 1984 : 132-35), but Anuta is one of the few islands whose population still depends upon this method.

$M a$ is preserved through semi-anaerobic fermentation of peeled, uncooked tubers or fruit in circular subterranean pits (rua ki ma) ranging from 1-2 m diameter, and 1-1.5 m deep, lined with Alpinia or Heliconia leaves (Fig. 3), and sealed on top with a layer of stones. If the leaflining is renewed from time to time, the fermented and preserved $m a$ may last for as long as 15 years, to be drawn upon as needed. On Anuta, $m a$ is prepared primarily from taro and manioc, but also from breadfruit, bananas, Cyrtosperma tubers, and Burckella (natu) fruit. Taro and manioc $m a$ tends to be stiff and starchy, while that made from natu fruit is strongly acidic. As to be expected with a fermented food product, $m a$ has a strong pungent odor and taste, adding significant taste variation in the Anutan diet. Yen (1973: 127-28) describes variations in the preparation of $m a$.

Another form of food « storage » or resource buffering is provided by several crop species that have long or indefinite maturation times, and which are therefore only harvested intermittently when need requires. These include the stands of puraka aroids with their massive, fibrous corms, and the sago palms which yield yet another form of storable starch.

\section{Anutan Food Preparation and Cuisine}

\section{The Oven House}

The key locus of Anutan food preparation and thus also a major space of social interaction within the patongia - is the pare umu, literally the " house oven ». Each patongia possesses its own pare umu, situated inland of the dwelling houses (pare moe), either set in among the orchard gardens or along te marae tika (the dart pitch), but connected to the dwelling by a path. These oven houses are roughly $5 \mathrm{~m}$ long by $3 \mathrm{~m}$ wide, and between 1.5 and $2 \mathrm{~m}$ high, with sloping thatched roofs and open sides. As the eaves lie no more than $1 \mathrm{~m}$ above ground, however, one must enter the oven-house by crawling on all fours, 


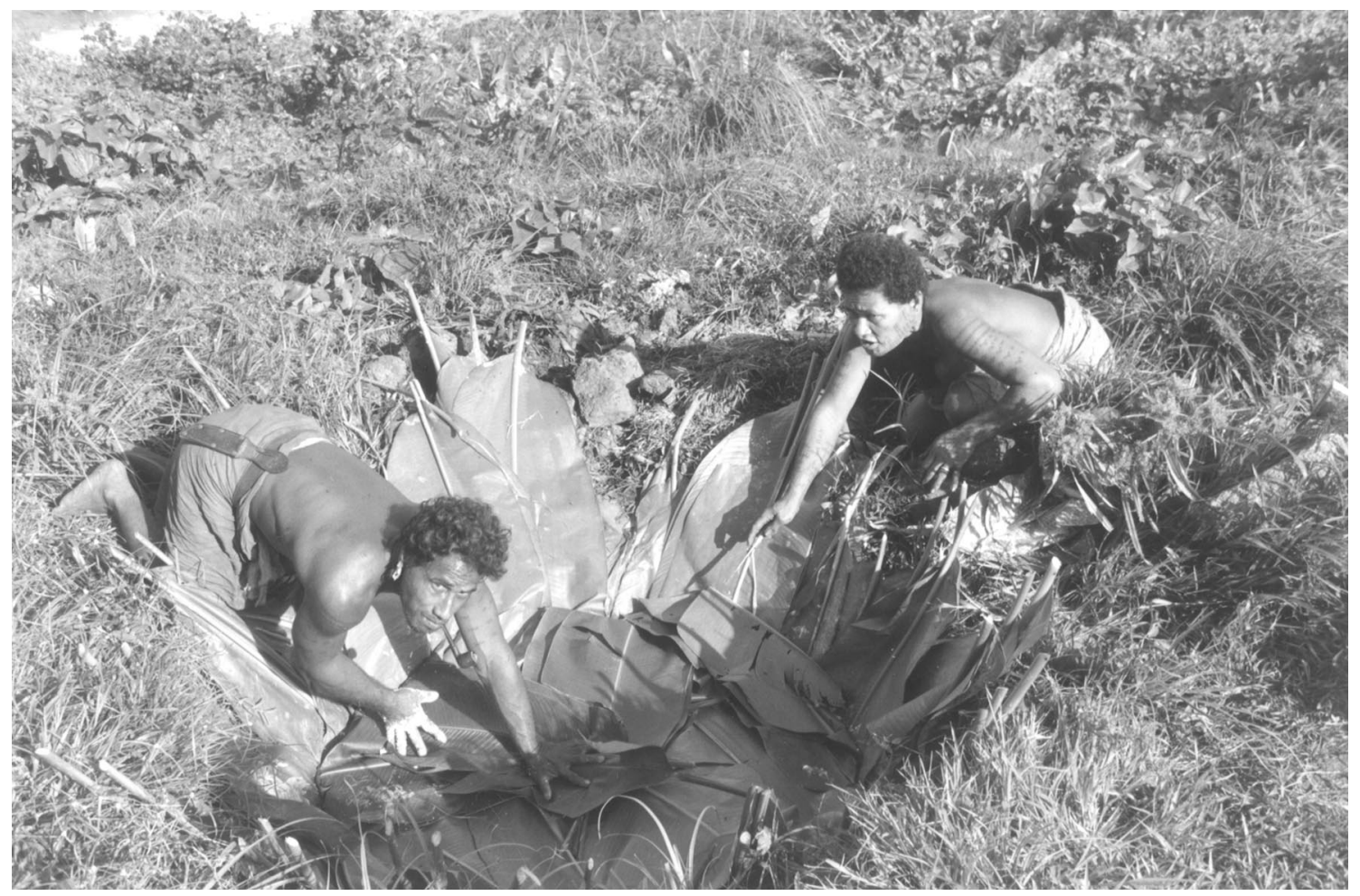

FIG. 3. - Sealing a ma pit lined with Heliconia leaves.

and as in the Anutan dwellings, one moves about on the house floor by crawling or scooting; all cookhouse activity takes place with the participants in a seated position. The cleared space surrounding an oven-house is typically littered with the debris of food preparation : coconut husks, broken shells, leaves and other vegetal trash are strewn about. When not in use, such cooking implements as grater stools, wooden bowls, and husking sticks are also lying around or in the house. Other, two or more ma storage pits are found in the immediate vicinity of the oven-house.

Bending down and crawling into an Anutan oven house, the visitor find the frame and sagothatched roof to be supported by four stout posts; the ceiling is blackened and encrusted with soot from repeated oven fires. A range of objects are stored in the rafters or set on racks suspended from the roof. Towards one end of the house is the oven itself, te umu, a pit about $1.5 \mathrm{~m}$ across and $1 \mathrm{~m}$ deep. The remainder of the earth floor, black with soot and charcoal, is littered with vegetal debris, with a few coconut frond mats (tapakau) lying about. The pare umu of Patongia Pangatauriki, as examined between cooking sessions, contained a large food bowl (napa) used for making sago flour and turmeric dye. On top of this and nearby were four smaller bowls (kumete) used for everyday cooking and preparation of puddings. Coconut frond baskets (popora) were scattered about, and one held a batch of smaller firewood and kindling. A pile of larger pieces of firewood lay against one of the posts, while a pile of old rau puraka or Cyrtosperma leaves used for covering the oven was close by. A single $m a$ pit could be seen immediately inland of this oven house.

\section{Preparing the Oven}

The $u m u$ is oven for cooking virtually every type of Anutan food. While fish may be broiled over an open fire, and already cooked foods are often re-heated over the dwelling hearth, fresh starch food is invariably cooked in the earth oven. As already noted, the umu consists of a simple pit in the ground, about $1 \mathrm{~m}$ deep and 1.5 $\mathrm{m}$ in diameter. The oven stones (patu umu) are specially selected and must be of porous quality so they do not explode when heated. A supply of these stones is always kept in a heap close to the oven. The sequence of preparing and cooking food in the umu, called pai umu, is as follows :

- Tе uти ku pu : lighting the oven. The oven pit is first cleared of stones and ash from the previous firing, usually a few days previous, and the sides of the pit are scraped clean with 
TABLE 3

Objectif Used in Food Preparation

\begin{tabular}{|c|c|c|c|c|c|}
\hline $\begin{array}{c}\text { Anutan } \\
\text { Term }\end{array}$ & Object & Function & Material & Permanent & $\begin{array}{l}\text { Temporaryl } \\
\text { Disposable }\end{array}$ \\
\hline Uo & $\begin{array}{l}\text { Husking } \\
\text { Stick }\end{array}$ & Husking coconuts & Wood & \pm & \\
\hline Kue & Scraper & $\begin{array}{l}\text { Scraping tubers } \\
\text { and corms }\end{array}$ & Bivalve shell & $\mathrm{X}$ & \\
\hline Ele & Scraper & $\begin{array}{l}\text { Scraping rind of } \\
\text { fruit }\end{array}$ & Shell & $\mathrm{X}$ & \\
\hline Vakautuei & $\begin{array}{l}\text { Coconut } \\
\text { grater }\end{array}$ & $\begin{array}{l}\text { Grating flesh of } \\
\text { coconut }\end{array}$ & $\begin{array}{l}\text { Wooden stool } \\
\text { with shell grater }\end{array}$ & $\mathrm{X}$ & \\
\hline Paota & Grater & Grating starches & Wood & $\mathrm{X}$ & \\
\hline Tina & Grater & Grating starches & Wood & $\mathrm{X}$ & \\
\hline Vakai & Strainer & $\begin{array}{l}\text { Expressing coconut } \\
\text { cream }\end{array}$ & Bark & & $\mathrm{X}$ \\
\hline Kumete & Bowl & $\begin{array}{l}\text { Storing and mixing } \\
\text { foods }\end{array}$ & Wood & $\mathrm{X}$ & \\
\hline Napa & Large bowl & $\begin{array}{l}\text { Preparation of sago } \\
\text { and turmerie }\end{array}$ & Wood & $\mathrm{X}$ & \\
\hline Pangongo & Cup, spoon & Handing liquids & Coconut shell & \pm & \\
\hline Rakau toro & Oven sticks & $\begin{array}{l}\text { Pushing hot stones } \\
\text { in food bowls }\end{array}$ & Wood & \pm & \\
\hline Anganga & Tongs & $\begin{array}{l}\text { Handling hot stones } \\
\text { or burning wood }\end{array}$ & Pandanus roots & & $\mathrm{X}$ \\
\hline Tuki & Pestle & $\begin{array}{l}\text { Mashing food for } \\
\text { puddings }\end{array}$ & Coconut frond & & $\mathrm{X}$ \\
\hline
\end{tabular}

the hands. Kindling (often dried coconut endocarps) is placed in the bottom and lighted with a burning stick or smoldering piece of coconut husk brought from elsewhere for the purpose. If no fire is immediately available, it can be produced by the tika api method of rubbing a pointed hardwood stick against a stationary piece of softer wood with a groove.

- Te umu ku ka: the oven burns. Heavier firewood (papie) is now added, and after a blaze has commenced, the oven stones are carefully wedged on top of the burning wood. They are thus heated to a red hot condition.

- Te umu ka taro: spreading the stones. Once the fire has burned down and the stones are sufficiently heated, they are spread out evenly on the bottom of the pit, using two long sticks (toro umu). Any pieces of burning wood are removed with tongs (anganga) fashioned from coconut midrib. Fresh large swamp taro leaves (rau puraka) are then placed over the stones.

- Te umu ku tao : the oven is covered. Food to be cooked is now added, either whole or in leaf wrappers, and covered over with puraka leaves. Finally, the entire oven pit is sealed with a covering of brown puraka leaves pinned together to form a kind of mat (repa), and the oven is thus left to steam.

- Tе ити ku тои: the oven is cooked. When the steaming is completed, after one to two hours, the repa is removed and the cooked contents taken out, either for immediate consumption, or for further processing into puddings (see below).

\section{The Material Culture of Cooking}

A very small number of tools and implements serves for Anutan food preparation; these are itemized in Table 3. A few items are temporary and disposable in nature, but most are durable and counted among the valued property of the patongia. This is particularly so with the larger food bowls, carved from large branches or trunks of Callophyllum inophyllum trees which are grown for this purpose along the coastal strand. Also highly valued is the vakautuei or coconutgrating stool, rather elaborately carved from two pieces of Callophyllum wood; these formerly had shell graters lashed to the projecting end, which have more recently been replaced with 
pieces of iron. The vakautuei is essential for grating coconut meat, which is then expressed into cream using the vakai bark strainer.

Another set of objects essential in Anutan cooking and cuisine consists of plaited baskets, of which there are six lexically differentiated forms. These are classified in two major categories, rau takiro baskets made from the young and finer leaves of coconut, and rau niu made from mature coconut fronds. The former includes (1) te tanga and te tapeta, two forms of small basket used to hold betel nut chewing ingredients ; (2) te kete, for holding smaller fish ; and (3) te longi, a "kit" basket for holding an individual's share of cooked food. The longi baskets are hung from the dwelling-house rafters between meals. Coarser rau niu baskets include te popora, a large form used to hold and transport raw food such as tubers or fruit, and te rourou, a plaited serving "platter" and which cooked food may be presented.

The material culture of cooking on Anuta has been little affected by external contacts, with the exception of steel knives which are highly prized and ubiquitous. Also prized are large aluminum tea kettles of the kind sold by Chinese trade stores in Honiara ; these are used to hold water, which is drunk directly from the spout. I never saw these kettles used over a fire.

\section{Oven-House Activity Patterns}

In addition to the stages of oven preparation already described, oven-house activities are largely organized around the work of preparing starchy foods (tubers or fruits) for cooking, and of mixing and pounding starch and emollients to produce puddings of various kinds. The following verbs describe key actions in the preparation of raw foods : (1) ari, to scoop out, as in the scraping out of coconut meat; (2) oro, to grate or shred; and (3) vau, to scrape or remove the skin of tubers, etc. Scraping the skin off of a taro tuber with a bivalve shell, in preparation for cooking, is shown in Figure 4. With the preparation of puddings, the main action terms are : (1) takai, to mix by stirring; (2) natu, to knead, using the hands ; and (3) tuki, to pound, using a pestle fashioned from the base of a coconut frond (tuki). The sequence of activity within an Anutan oven-house is best conveyed through description of specific instances observed in the field, in this case an ordinary household cooking sequence, and a feast preparation sequence.

Case 1: Normal Household Cooking. The sequence to be described occurred on December
10,1971 , between roughly $3: 30$ to $5: 30$ in the afternoon, in the oven-house of $\mathrm{Pu}$ Akonima. The activity group consisted of Pu Akonima and his wife Nau Akonima, along with Mataamako, $\mathrm{Pu}$ Akonima's sister's son who helped with some preliminary chores. During this sequence, the Akonima's adopted son, only a few months old, was also in the oven-house. The food prepared during this sequence supplied the Akonima patongia, comprising eight persons, for three days.

The Akonima oven-house lies just off the main trail between Vatiana and Rotoapi, in an area of coconut, puraka, and various other orchard crops. A $m a$ pit containing fermented manioc paste is situated close outside of the house. In the house rafters $\mathrm{Pu}$ Akonima had stored a paota grater, a net loop and pole missing its mesh, and several canoe masts, while lying on the ground at the opposite end from the umu was the hull of a small canoe (Figure 5). In the early afternoon, Nau Akonima assisted by Mataamako had prepared a fire in the oven pit, and had peeled or scraped the skin from a batch of freshly gathered breadfruit, which was in season. During this time $\mathrm{Pu}$ Akonima, using his vakautuei grating stool (\#1 in Figure 5) on the ground outside the house, had grated fresh coconut meat into a wooden bowl (\#2); the grated meat was then further expressed into coconut cream (roro) using a vakai strainer of Hibiscus bark. The vakai is used to scoop up a batch of grated coconut, then twisted and squeezed until the liquid runs out of the coconut flesh. The squeezed morsels of coconut meat are then shaken out on the ground (where they are consumed by chickens), and the process repeated until the bowl contains only fresh cream.

With the ingredients of the uоu mei or breadfruit pudding thus prepared, $\mathrm{Pu}$ Akonima fetched a coconut frond, cutting the midrib with his bush knife, and quickly produced a tuki pestle about $1 \mathrm{~m}$ long, with a blunted end. At the same time, Nau Akonima began to take peeled breadfruit from a popora basket (\#6), and using a large puraka leaf (\#7) for her working surface, removed the seeds (tenga) from the fruit, then tossed these one by one into a second wooden bowl or kumete (\#3). Pu Akonima then entered the house and seating himself on the ground opposite his wife, began to pound the seedless breadfruit with the tuki pestle. Having finished removing the breadfruit seeds, Nau Akonima then turned to the task of readying the pudding wrappers (kopu) from swamp taro and banana leaves, these leaves being taken out of a basket (\#5) brought in earlier by Mataamako who had 


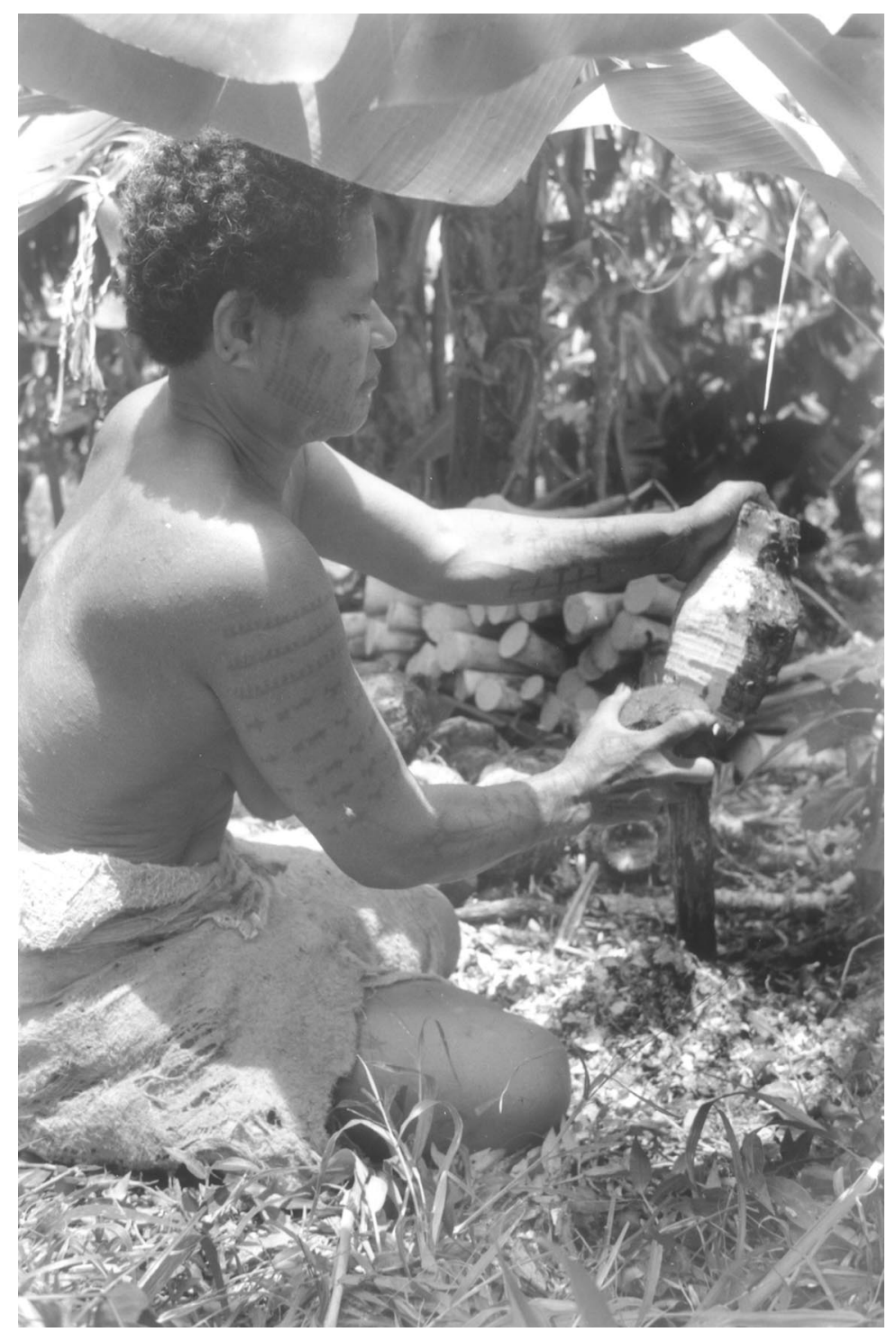

FIG. 4. - Scraping a taro tuber with a bivalve shell.
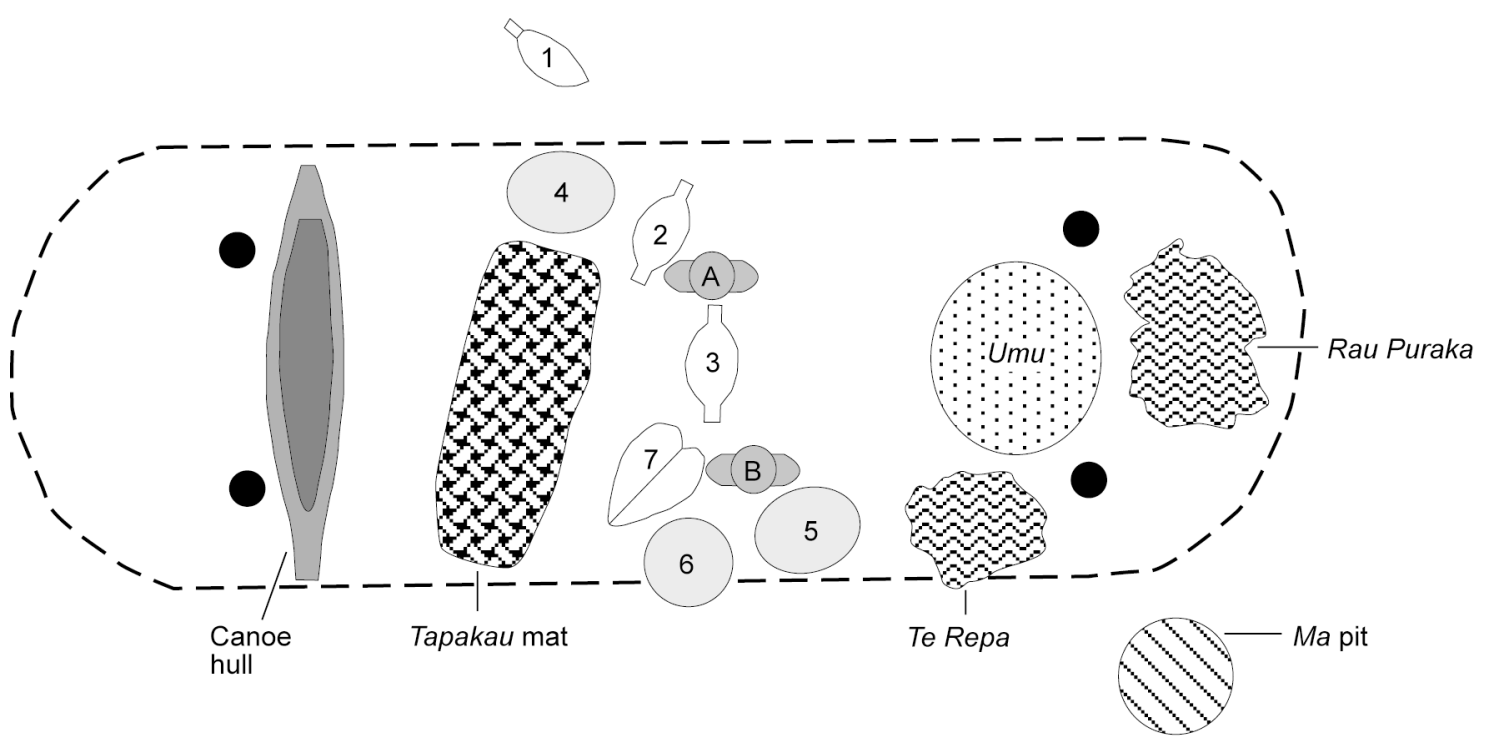

FIG. 5. - Plan of oven-house during normal food preparation (see text for explanation). 
obtained them in the orchards. Meanwhile $\mathrm{Pu}$ Akonima adds the coconut cream (from bowl \#2) into the breadfruit mass he is pounding with the tuki, ladling the cream with a coconut halfshell (pangongo). When he has judged the starchy mass to be sufficiently pounded and mixed with coconut emollient, Nau Akonima begins to pass him the prepared leaf packages, each with banana leaves on top and a large swamp taro leaf below. Using a pangongo lined with a banana leaf to avoid sticking, Pu Akonima spooned out a batch of the pounded breadfruit-coconut mass onto each wrapper. Nau Akonima then took these one by one, folding the leaves up and fastening them with rau takiro fiber. The completed parcels are then placed in the now-readied $u m u$ to cook. When opened a couple of hours hence, the kopu parcels are transported to the dwelling house in a large popora basket, ready for the patongia meal.

Case 2 : Cooking for a Feast. My second example of oven-house activity took place on November 1, 1971, in anticipation of a feast the following day, associated with the funeral of a young child (the son of $\mathrm{Pu}$ Akonima) who had just died. The oven-house used in this case was similar to that just described, set in a small clearing off the trail between Vatiana and Te Marae. A large umu nearly $2 \mathrm{~m}$ in diameter took up a large part of the floor space, which was otherwise covered in coconut fronds and vegetative debris. Coconut husk (puru) was drying in the soot-blackened rafters, for later use as kindling, and several pairs of Pandanus-tongs (angaanga) were also stored there. A husking stick (uo) was implanted in the earth outside this pare umu. Equipment used in the cooking sequence to be described included four elongate kumete bowls, two round kumete, three vakautuei grating stools, various tongs, pestles and pangongo shells, vakai strainers, baskets, and te rakau toro sticks. Figure 6 shows the plan of this oven-house during two stages in the cooking sequence.

As these preparations were for an island-wide feast, the tasks of procuring raw foodstuffs had already been going on for several days. A large quantity of starch staples, including taro corms, puraka corms, and manioc tubers had been harvested from the hill gardens during the morning, and $m a$ paste of both taro and manioc was also procured from the fermentation pits. Canoe fishing during the previous night had yielded quantities of bonito (varu), codfish (parumairei) and several kinds of red snapper (panamea, taimea), as well as shark (mango). These fish had been parceled in leaves and placed in a large earth oven used only for fish (umu ika), situated under the shelter of the cliffs at the canoe landing.

In the oven-house, the $u m u$ had been prepared around noon, with both grated taro and whole taro corms placed inside to steam. While the oven was cooking, the process of preparing the emollients and food packages was underway. This involved first grating and expressing the coconut meat into cream, which was temporarily kept in one of the elongate kumete bowls. Heated stones from the oven were then dropped into the kumete and moved around with long sticks (rakau toro) so that the stones would not settle and burn the wood ; after a number of minutes the white coconut cream was gradually rendered into a light brown, fragrant-smelling coconut oil (roro tutu), which was then transferred to one of the round kumete.

Next, a new batch of seed coconuts (those which had already begun to sprout) was brought to the oven-house, husked, and split open with a bush knife. The oko or spongy growth within these coconuts was removed and set aside in a basket for later consumption, although a few oko were eaten on the spot by the workers. The meat of these coconuts was grated by two men into a kumete, and expressed into cream using a vakai strainer. Meanwhile, several women inside the oven-house were preparing bundles of puraka leaves to be used for the food packages.

The umu was now judged to be fully cooked, and the repa covering of leaves removed. Lumps of cooked, previously grated taro were taken from the oven pit by the women and tossed quickly into three kumete bowls inside the house. The men sprang into action, pounding the taro with tuki pestles; coconut cream was then mixed in, using a pangongo ladle. The resulting uoua pudding was proportioned out into the puraka and banana leaf parcels, again using a pangongo wrapped with a banana leaf. Three full bowls of taro were thus converted to uоua taro.

The fourth kumete was now filled with cooked whole taro corms fresh from the oven pit, which were similarly pounded, but this time mixed with the rendered coconut oil, resulting in a dish called tukipei. Small handfuls of the tukipei were snatched up and rolled into small balls about 5 $\mathrm{cm}$ in diameter, in the palm of the hand. These balls were then stacked together in several leaf packages, creating a special delicacy known as te poke.

As can be seen in the two oven-house sequences described above, both men and women participate equally in the work of food preparation, yet each gender has certain specific tasks nor- 


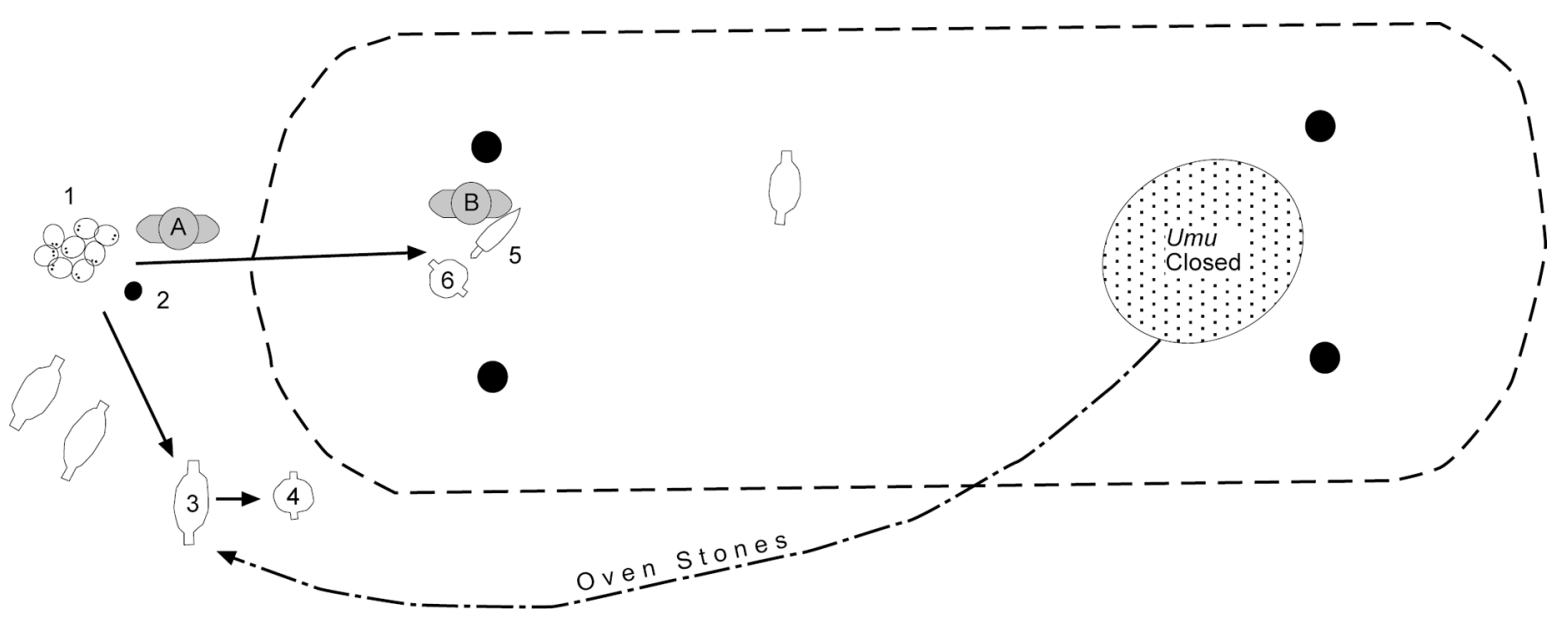

$1 \quad$ Pile of coconuts

$2 \quad$ Husking stick

$3 \quad$ Kumete with coconut cream

$4 \quad$ Kumete with coconut oil

$5 \quad$ Coconut grating stool

6 Kumete with coconut cream

A Man husking and splitting coconuts

B Man grating coconut meat

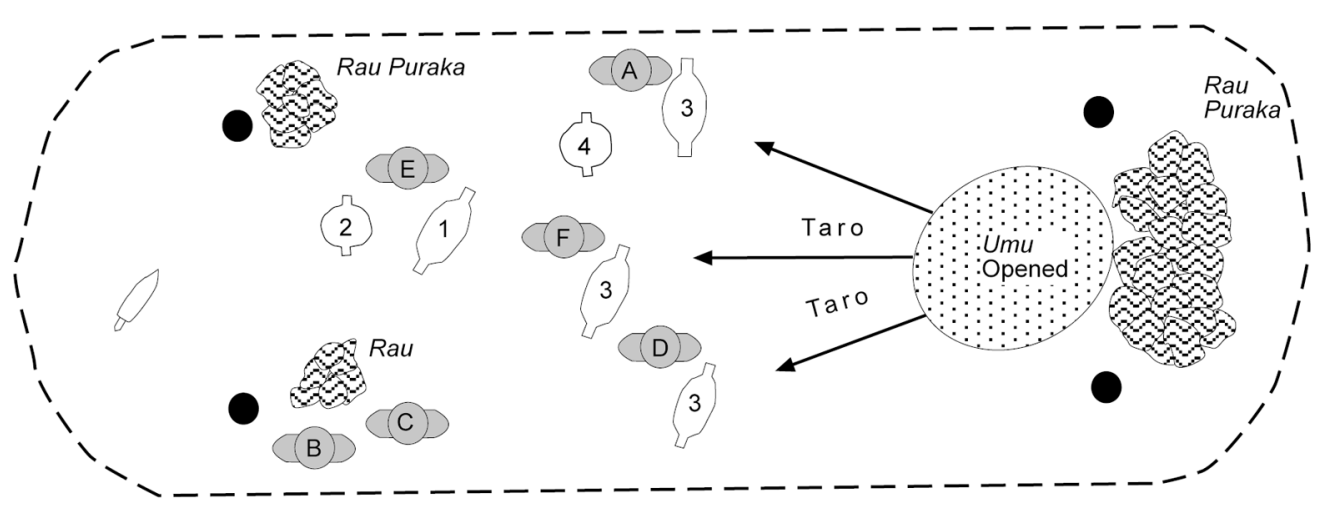

$1 \quad K u m e t e$ with taro corms for te poke

2 Kumete with coconut oil for te poke

$3 \quad$ Kumetes with taro for uoua taro puddings

$4 \quad$ Kumete with coconut cream for puddings

$A, D, E, F$ Men pounding puddings

$\mathrm{B}, \mathrm{C} \quad$ Women wrapping puddings

Fig. 6. - Plan of oven-house at two stages during food preparation for a feast (see text for explanation).

mally assigned to it. Oven preparation, the grating of tubers, and the preparation and wrapping of food parcels are tasks typically carried out by women and girls. Husking and grating coconuts, expressing coconut cream and rendering it into oil, and the pounding of puddings is generally men's work. Young children are assigned all manner of lesser chores, such as fetching water or firewood.

\section{Major Categories of Prepared Foods}

From the two examples of cook-house activity just presented, it should be clear that Anutan cuisine has two main variants, a starch base (kai) prepared either singly (such as taro or manioc tubers steamed in the $u m u$ ) or mixed with an emollient to produce a pudding (иоиа). Coconut cream (roro) is the most commonly used emol- 


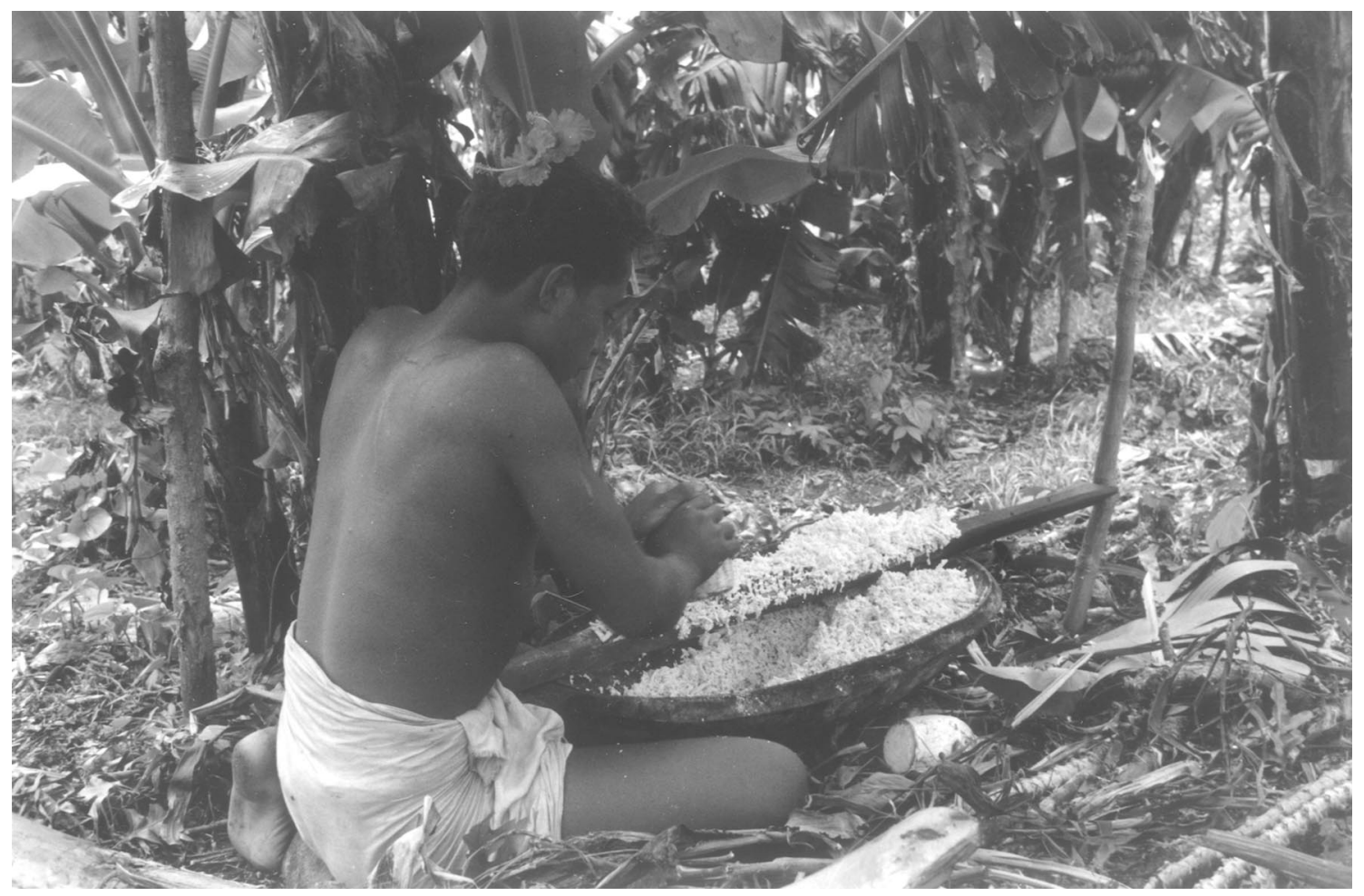

FIG. 7. - Grating taro in preparation for making a pudding.

lient, although for some special dishes coconut oil (roro tutu) is used. The sequence in transforming coconut meat to one of these emollients is thus :

$$
\begin{aligned}
\text { niu } & \rightarrow \text { Grating } \rightarrow \text { ngoniu } \\
\rightarrow \text { Squeezing } & \rightarrow \text { roro } \rightarrow \\
\text { Stone Boiling } & \rightarrow \text { roro tutu } .
\end{aligned}
$$

In preparing puddings, two different starch bases are never mixed together. A good pudding should always have a generous amount of emollient mixed into it, which renders the dish makara, 'sweet' or 'pleasant tasting' (as opposed to kona, 'bitter' or 'harsh tasting'). Cookhouse etiquette requires a guest to proclaim, on first tasting a freshly prepared pudding, e makara, 'it is sweet'.

Puddings are also distinguished on the basis of whether the starch base is first grated prior to baking (as shown in Fig. 7) which are called te uoua oro, or whether the starch is baked entire and then mashed with a coconut frond pestle (tuki) yielding puddings called te tukipei uoua. The following lexically-marked variations of uoua were observed or described to us :

- Uоua mei. Fresh breadfruit (mei) are scraped to remove the skin, cut open and the central pith and seeds removed, and then cooked in the umu. After cooking, the fruit are placed in a wooden bowl, and pounded with a tuki pestle while coconut cream is added.

- Uoua taro. Taro corms are first grated while still raw, the grated starch then wrapped with banana or Cyrtosperma leaves to form small parcels which are baked in the oven. After cooking, the grater taro is mixed with coconut cream. Variations of this kind of pudding may be made substituting manioc, banana, yams, or Cyrtosperma for taro, in which case the puddings are known variously as uoua manioka, uоиа puti, uoua upi, or uoua puraka respectively.

- Uoua ma taro. Puddings may also be made by using the semi-anaerobically fermented $m a$ paste as the base. The taro tubers used to make $m a$ were previously grated prior to fermentation, so the paste is simply dug up from the pit, cooked in the oven, and mixed with coconut cream. Uoua ma has a strongly pungent taste. Variants include puddings made from other kinds of ma, such as ma manioka or ma puti.

Another major category of prepared food is te poke, a special food often prepared for feasts, or for presentation to the chiefs. Poke is most often made of taro, although it can also be produced from breadfruit or manioc. The cooked starch (either first grated or cooked whole and then 
pounded, as in uoua preparation) is mixed with coconut oil (roro tutu) and then rolled into small balls (ca. 4-5 cm diameter), which are stacked together into a leaf parcel. Yet another variant on the pudding theme is achieved by a second baking of a mixed pudding base which has been wrapped into leaf parcels ; this kind of twicebaked pudding is called te roi.

A final variation in prepared starch foods comes with the use of dried flour made either from the sago palm pith (koko) or from the tuber of Polynesian arrowroot (maoa). We did not witness either the preparation of these flours, or the preparation of puddings made from them, during our stay. However, the process of flour extraction as described to us corresponds to that in nearby Tikopia, a filtration process using water to extract the starch, which is then gradually decanted and sun dried. Kept dry, the flour will last for some time, and provides another kind of starch food reserve in times of famine. Te koko or te maoa was said to be mixed with fresh coconut, yam, or banana to form puddings.

Prepared starch foods are served up in food parcels $(k o p u)$ in a standard pattern, using a limited number of kinds of leaves. Uoua puddings are invariably wrapped first in banana leaves and then in a large swamp taro (Cyrtosperma) leaf. Te poke puddings are wrapped first in rau paopao (Heliconia sp. leaves) and then in a swamp taro leaf.

Open-fire roasting, called tunu, is another method of cooking that should be mentioned. This is frequently done with breadfruit (mei tunu), which are roasted directly over heated stones. After the skin is charred and the flesh cooked, the skin is peeled off with a small stick and the hot breadfruit consumed either by itself, or preferably dipped into a pangongo shell of freshly-squeezed coconut cream.

\section{Preparation of Flesh Foods}

The main flesh foods (kanopi) consumed by Anutans are fish (ika), seabirds (manu), and chickens $(\mathrm{kio})$. Fish are typically prepared for cooking by puncturing the organ cavity with a finger and roughly removing the contents, then flushing with sea water (the process takes place at the ocean edge); fish are not scaled. After this crude cleaning, the fish are wrapped in a single leaf (breadfruit, Heliconia, and Cordyline leaves are used) and baked whole in the uти. Fish may also be roasted (tunu) over an open fire ; previously cooked fish are often re-heated in this manner. Small fish are often not gutted. A special fish dish, called toputopu, is made by boiling fish in water mixed with coconut cream ${ }^{4}$.

Seabirds are killed by biting the back of the neck and thus breaking the spinal column. They are plucked, and cooked whole in a single leaf parcel as with fish. When consumed hot and fresh from the oven they are delicious, but when consumed cold take on a strong odor and taste of fish. Chickens are plucked and the feet and head removed; the body is then placed on a bed of taro or pukovai (Cordia subcordata) leaves, this ensemble being wrapped first in banana leaves, then parceled in swamp taro leaves, and baked in the earth oven. The taro and pukovai leaves are consumed along with the chicken.

\section{The Folk-Taxonomy of Food}

The Anutuan classification or folk-taxonomy of 'food' is diagrammed in Fig. 8. There is no cover lexeme for both liquid and solid foods, but the general term kai in its unmarked sense can be used for both vegetable and animal foods. Vai refers in its unmarked sense to potable liquids, in its marked sense to 'fresh water', as opposed to coconut water (vai niu). As with virtually all other Polynesians, Anutans make a key distinction between the marked sense of kai, vegetable foods and particularly starch staples, and $k a n o p i$, flesh foods. The latter include fish ( $i k a)$ of all kinds, seabirds (manu), and chickens (kio). It is significant that kai refers both to starch food and to food in general, for as we have seen an Anutuan meal can be minimally constituted with cooked starch alone, but not with meat or flesh alone.

At a lower level in the hierarchical classification of foodstuffs, kai is further distinguished into kai mata, 'raw' or 'uncooked' vegetal foods and kai mou, 'cooked food'. Some vegetal foods are, of course, eaten while raw, such as bananas or coconuts, but most starchy foods must be cooked to be rendered edible. These cooked foods, kai mo, are further distinguished by the degree to which they are further transformed in the culinary process. Thus the various kinds of puddings (uoua, poke) are classified in opposition to simple kai tao, 'oven food', which consists of baked tubers such as taro, manioc, and puraka. Uoua puddings are further divided according to whether they are made from grated 


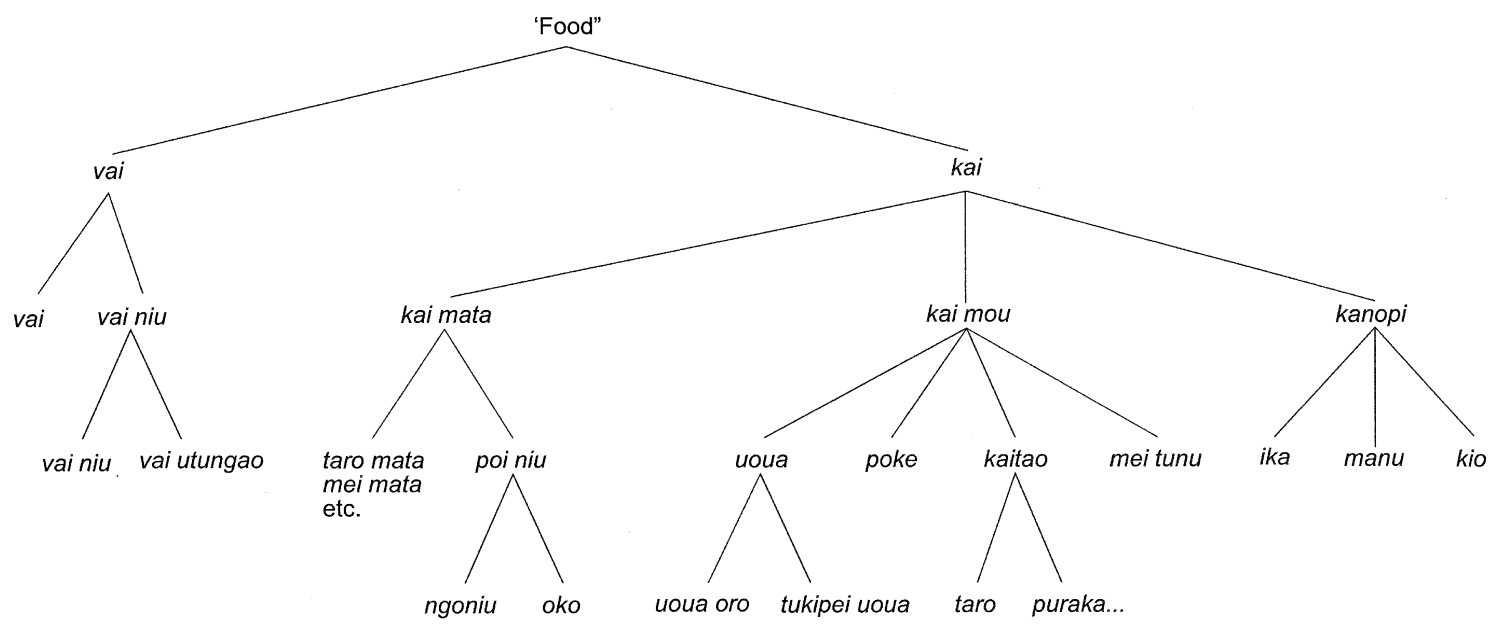

FIG. 8. - The Anutan folk-taxonomy of food categories.

starch (иоиа oro) or from whole cooked tubers which were then pounded (tukipei uоua).

\section{The Social Dimension of Food}

In a small-scale, subsistence based society such as Anuta, the endless round of growing, harvesting, preparing and consuming food dominates the practices of everyday life, the habitus around which the social order is constructed (Bourdieu, 1977). The work of obtaining and preparing food is socially structured in complex ways, but it is the act of consuming food which more than anything defines the basic social order (see Bell, 1931). Anutans eat only one main meal during the day, generally in the later afternoon when the oven-house activity and other tasks have been completed. The focus of this main meal is kai mo, cooked starch food, which must be present to constitute a meal proper (i.e., raw foods, or flesh alone, are not sufficient). Often a meal includes both kai tao, starch foods cooked in the umu, as well as some kind of prepared foods such as a uoua pudding, but if coconuts needed to make the latter are scarce, kai tao alone may be served. Likewise, some kind of kanopi, usually fish, is desirable to supplement and complement the kai, but this is not absolutely required. Seabirds and chicken are forms of $k a n o p i$ consumed far less frequently than fish.

Cooked foods of all kinds are stored between meals in the finely-plaited longi baskets which hang from the rafters of the dwelling house. As members of the household rise in the pre-dawn, they reach for the longi and bring them down to the mat-covered floor, where any who desires a bit of cold food takes some ; there is no formality about eating at this time. Throughout the day, people also satisfy their hunger with impromptu snacks, such as fruit or nuts, and of course betel nut is often chewed. Children, especially, are frequently to be seen snacking on coconut meat, the spongy oko coconut germination, a piece of sugar cane, kauariki nuts, or breadfruit seeds.

Although a meal is sometimes taken in the oven-house immediately after cooking, the usual pattern is to place the food in the longi kits and transport it to the pare moe dwelling house, where the patongia then takes its meal more formally. The pare moe has its own delineation of space, organized along geographic, sacredprofane, and gender axes. As in the Tikopian house (described by Firth, 1936: 75-81 and by Kirch, 1996 : 261-62), the Anutan dwelling has an inland, profane, and female side called tuaumu ('back of the oven'), and a seaward, sacred, and male side called matapare ('face of the house'). These sides are not physically marked by walls or divisions, yet they are real enough, and the positions and movements of persons within the house constantly reflect them. In between tuaumu and matapare is roto a pare ('middle of the house'), a neutral space.

Matapare, which is generally the side of the house closest to the sea, is the traditional seating place of men, and in pagan times mats representing the house ancestors were placed there. Tuaumu, in contrast, is the seating and working area of women and children, and it is here that the small hearths called tapungapi are situated. Women and children always enter the house from doorways situated on the tuaumu side, whereas men enter from the ends of the house. During the night, members of the household sleep with their heads toward matapare and their feet toward tuaumu. The positioning and 
consumption of food, as one might anticipate, is organized along these same principles. When the longi food kits are brought into the house, they are placed in the central roto a pare space, and the household members gather (seated crosslegged in the case of men, legs extended and together in the case of women) around the food, men on the matapare side and women and children on the tuaumu side.

Once the patongia members have gathered in their relative positions on the tapakau mats covering the floor of the pare moe, several large swamp taro leaves (rau puraka) are laid down in the center space, and the food is distributed, usually by one or two of the younger men. Puddings, chunks of kai tao, or fish are laid out on the puraka leaves in front of each person. Often uoua puddings are shared, although a separate pudding is typically prepared for a man of rank such as the patongia elder or one of the chiefs. Morsels of food are taken up between the thumb and first two fingers of the right hand. Thus with puddings one scoops out a small lump of the starchy mass, rolls it between the thumb and fingers, and places it in the mouth.

Anutans take great satisfaction in the communal act of eating, and it is expected that the household head should urge his fellow diners to eat heartily: kai toa, 'eat friend' he will say repeatedly to a guest. Eventually all express their contentedness with the term makona, 'full, satisfied.' Liquids are generally not taken simultaneously with solid food, but after the main part of the meal is finished. The water will be drunk either from small coconut shell bottles (the traditional form of container), or today more commonly from aluminum kettles prized for this purpose. Drinking coconuts may be given to persons of rank or visitors in lieu of water, who are again urged to drink (inu) to their full. At meal's end, fingers are cleaned on freshly shredded coconut husk (puru mata) which is passed round for this purpose, and the unconsumed food is wrapped up again and placed in the longi kits which are then suspended from the rafters.

With the longi hung from the rafters, it is time for the passing around of betel nuts (kaura) which are generally chewed by all except young children. A bunch of nuts and bundle of Piper betel leaves (pita) are passed around those present, each person taking some. A gourd containing lime (kapia) follows, and the lime is shaken onto the leaf and nut, with the package placed in the mouth and masticated. The reddened saliva is expectorated out any convenient doorway, or under a lifted mat.
Beyond the everyday consumption of food by the patongia, there are many occasions throughout the course of a year when larger social groups, such as the kainanga (the eponymous ascent group) or the kanopenua (the total island population), gather to share food. Feinberg (1981 : 114-22) discusses a number of rites de passage during which presentations of food and/or ritualized feasting are essential. One of these is pangai ika, the first feeding of fish to a year-old first-born boy or girl, for which all of the island's patongia make an oven and present food « on behalf of the father », while the maternal kinsmen "feast in the tupuna's house while the father's relatives eat outside » $(1981: 114)$ Later in life, children go through a rite known as the angaa which requires substantial preparation in terms of accumulating sufficient food stocks to host an entire week of feasting. Another life crisis requiring significant feasting is circumcision, and Feinberg remarks that the timing of this rite depends in part on « the condition of his patongia's gardens » (1981: 117). Weddings are accompanied by a feast to which each patongia on the island contributes, but with a disproportionate amount of the food coming from the gardens of the groom's family. Feinberg relates that following the main wedding feast, « for the next two to three weeks, each day a different patongia brings presents of food to the newly married couple. In theory the man's relatives are supplying him with food, and the woman's kin are supplying her. In fact, all food is accepted by the couple and shared with the man's patongia. This practice is called te uke rongi $\gg(1981: 120)$.

Other regular occasions for island-wide (kanopenua) feasts are the Anglican Church of Melanesia holy days, which with the conversion of Anutans to Christianity in 1916 supplanted the former system of first-fruits and other pagan ritual prestations (see Feinberg 1981: 156-57). We participated in several such feasts in 1971, all of which were held in an open, sandy space shaded by large pukovai trees next to the old church in Vatiana. There being no resident priest on the island, the catechist (in 1971 this was $\mathrm{Pu}$ Tokerau, younger brother of the chief Ti Anuta) decides the timing and extent of the feast, instructing the various patongia on their obligations to contribute to the pending celebrations. Deep-sea fishing may commence several days beforehand to accumulate sufficient fish for the feast, or if the sea is rough, the population may undertake a communal fish-drive on the reef, as we witnessed. The various patongia prepare their ovens in the afternoon of the day prior to the feast, and following the early morning prayer on 
the appointed day, the ovens are opened and food carried to the feasting place. Each patongia has its own customary seating place where it spreads its tapakau mat of plaited coconut fronds, upon which its food basket is placed. Special food baskets are also presented to the chiefs (the paraariki basket) and to the catechist (the pakamisionari basket) The members of the patongia then eat together from the same basket, which is the quintessential defining act of the social unit. After the meal is concluded, dancing begins which may go on for hours, or into the evening. Some feasts last but a single day, but others may go on for two or three days.

\section{Summary and Comparison}

This paper has had as its aim a modest contribution to the ethnographic record of indigenous Oceanic food processing, a topic Oliver glosses as a « seemingly transparent and trivial but in some respects recondite and vital aspect of Island cultures " (1989: 280-81). Certainly the topic was of great interest to Jacques Barrau, who recognized that the domain of the ethnobotanist extended beyond plants per se to the myriad ways in which plant products are transformed to become parts of whole cultural systems. Throughout much of Polynesia today, acute cultural changes in foodways have greatly modified or even supplanted traditional cuisines; where the latter persist it is often in the context of tourist performances. Anuta, being unusually isolated and scarcely integrated with the larger world economic system, has preserved its historical cuisinary legacy.

Anutan food processing and cooking falls clearly within a broad category of Oceanic cuisine, and more specifically within a Western Polynesian-Outlier Polynesian subset of cuisines (these being somewhat distinctive, for example, from Eastern Polynesian cuisines). Thus, the emphasis on puddings in Anuta is reflected broadly throughout much of Austronesian-speaking Oceania, part of what Su'a (1987) has described as the "pudding complex». Indeed, many aspects of Anutan food preparation and processing can be traced historically to roots in the ancient Ancestral Polynesian cultures dating to ca. 2,500 years ago (Kirch and Green, 2001 : 143-60). This is the case with the fundamental distinction between starch (kai) and flesh (kanopi) foods, and the necessity for any 'meal' to include a starch staple. The following Anutan cooking terms, for example (by no means exhaustive), are all reflexes of Proto-Polynesian, and in some cases Proto-Oceanic lexemes :

\begin{tabular}{|c|c|c|c|}
\hline & Anutan & $\begin{array}{l}\text { Proto- } \\
\text { Polynesian }\end{array}$ & $\begin{array}{l}\text { Proto- } \\
\text { Oceanic }\end{array}$ \\
\hline Earth oven & umu & *qumu & *qumun \\
\hline Bowl & kumete & *kumete & \\
\hline Broil & tunu & *tunu & *tunu \\
\hline Starch food & $k a i$ & *kai & \\
\hline Cooked food & mo & *moho & *maosak \\
\hline
\end{tabular}

On the other hand, certain Anutan terms are clearly innovations, such as the general word for puddings, uоua, which is probably cognate with Tikopian susua, but has no Proto-Polynesian root. This serves to remind us that while cooking patterns are surely part of what Braudel (1980) called the longue durée of history, there was always change as well, even if very slowly.

In Anuta, such change also included the incorporation of new plants and animal products into the food ensemble, both in prehistoric and historic times. For example, the integration of betel nut chewing - a distinctly Melanesian trait reflects contacts between the Anutans (linguistically, of Western Polynesian origin) and their immediate Melanesian neighbors (e.g., Vanikoro, Utupua, Nendö Islands). In more recent times, a variety of new crop plants have been introduced and taken into the food production system, most notably manioc (which has largely supplanted yams in the intensive hill gardens) and tobacco.

The traditional Anutan food processing and cooking complex reflects the essence of a kind of cuisine - based fundamentally on a range of Indo-Pacific tuber, root, and tree crops, complemented by abundant marine protein but limited terrestrial flesh foods - that was until fairly recently shared by islanders over most of the tropical and subtropical Pacific. The emphasis on earth-oven cooking, supplemented by more limited roasting or broiling, and on the preparation of starchy puddings, are aspects of Oceanic cuisine with a deep history. It is a history that Jacques Barrau helped to unravel.

\section{REFERENCES CITED}

Barrau, J., 1961. Subsistence Agriculture in Polynesia and Micronesia. Bernice P. Bishop Museum Bulletin 219. Honolulu.

—, 1963. L'agriculture des îles Wallis et Futuna. Journal de la Société des Océanistes 19 : 157-71. 
—, 1965. Histoire et préhistoire horticoles de l'Océanie tropicale. Journal de la Société des Océanistes $21: 55-78$.

Barrau, J. and A. Peeters, 1972. Histoire et préhistoire de la préparation des aliments d'origine végétale : Les techniques d'utilisation de ces aliments chez les cueilleurs et les cultivateurs archaïques de 1'Australasie. Journal de la Société des Océanistes $35: 141-52$.

BELL, F. L., 1931. The place of food in the social life of central Polynesia. Oceania 2 : 117-35.

Bourdieu, P., 1977. Outline of a Theory of Practice. Translated by R. Nice. Cambridge : Cambridge University Press.

Braudel, F., 1980. On History. Translated by S. Matthews. Chicago : University of Chicago Press.

Cox, P. A. 1980. Masi and tanu 'eli : Ancient Polynesian technologies for the preservation and concealment of food. Pacific Tropical Botanical Garden Bulletin $10: 81-93$.

Di Piazza, A., D. Frimigacci, and M. Keletoana, 1991. Hommes au Four : Cuisine de Futuna. Nouméa : Éditions d'Art Calédoniennes.

FEINBERG, R., 1977. The Anutan Language Reconsidered: Lexicon and Grammar of a Polynesian Outlier. 2 vols. HRAFlex Books, Language and Literature Series: OT1-001. New Haven.

—, 1981. Anuta : Social Structure of a Polynesian Island. Provo : Institute for Polynesian Studies, Brigham Young University.

—, 1998. Oral Traditions of Anuta. New York : Oxford University Press.

FIRTH, R. 1936. We, the Tikopia. London : George Allen and Unwin.

_, 1954. Anuta and Tikopia: Symbiotic elements in social organization. Journal of the Polynesian Society $63: 87-131$.

Fox, J. J. (ed.), 1993. Inside Austronesian Houses : Perspectives on Domestic Designs for Living. Canberra : Australian National University.

HiroA, T. R., 1930. Samoan Material Culture. Bernice P. Bishop Museum Bulletin 75. Honolulu.

LÉvi-Strauss, C. 1982. The Way of the Masks. Translated by Sylvia Modelski. Seattle : University of Washington Press.

KIRCH, P. V., 1982. A revision of the Anuta sequence. Journal of the Polynesian Society 91 : 245-254.

_, 1984. The Evolution of the Polynesian Chiefdoms. Cambridge : Cambridge University Press.

—, 1994. The Wet and the Dry : Irrigation and Agricultural Intensification in Polynesia. Chicago : University of Chicago Press.

_, 1996. Tikopia social space revisited. In J. Davidson, G. Irwin, F. Leach, A. Pawley, and D. Brown, eds., Oceanic Culture History : Essays in Honour of
Roger Green, pp. 257-74. New Zealand Journal of Archaeology Special Publication.

—, 1997. The Lapita Peoples: Ancestors of the Oceanic World. Oxford: Blackwell Publishers.

—, 2000. Temples as 'holy houses': The transformation of ritual architecture in traditional Polynesian societies. In J. Gillespie and R. Joyce, eds., Beyond Kinship: Opening up the House, pp. 103-14. Philadelphia : University of Pennsylvania Press.

KIRCH, P. V. and R. C. GreEn, 2001. Hawaiki, Ancestral Polynesia : An Essay in Historical Anthropology. Cambridge: Cambridge University Press.

Kirch, P. V. and P. H. Rosendahl, 1973. Archaeological investigation of Anuta. In D. E. Yen and J. Gordon, eds., Anuta : A Polynesian Outlier in the Solomon Islands, pp. 25-108. Pacific Anthropological Records 21. Honolulu : Bishop Museum.

_ , 1976. Early Anutan settlement and the position of Anuta in the prehistory of the southwest Pacific. In R. C. Green and M. Cresswell, eds., Southeast Solomon Islands Cultural History : A Preliminary Survey, pp. 223-244. Royal Society of New Zealand Bulletin 11. Wellington.

MacGregor, G. 1934. Anthropological work of the Templeton Crocker Expedition, 1933. In H. E. Gregory, Report of the Director for 1933. Bernice P. Bishop Museum Bulletin 124. Honolulu.

Marck, J. 2000. Topics in Polynesian language and culture history, Australian National University Canberra, Pacific Linguistics 504.

Oliver, D. 1989. Oceania : The Native Cultures of Australia and the Pacific Islands. 2 volumes. Honolulu: University of Hawaii Press.

Pawley, A. 1967. The relationships of Polynesian Outlier languages. Journal of the Polynesian Society $76: 259-96$.

Steadman, D. W., D. S. Pahlavan, and P. V. Kirch, 1990. Extinction, biogeography, and human exploitation of birds on Anuta and Tikopia, Solomon Islands. Occasional Papers of the Bishop Museum $30: 118-153$.

Su'A, T. I. 1987. Polynesian Pudding Processes in East and West Polynesia. Unpublished M. A. Thesis, University of Auckland (New Zealand).

Thomas, N. 1989. Out of Time : History and Evolution in Anthropological Discourse. Cambridge : Cambridge University Press.

YEN, D. E. 1973. Agriculture in Anuta subsistence. In D. E. Yen and J. Gordon (eds.), Anuta: A Polynesian Outlier in the Solomon Islands, pp. 113-49. Pacific Anthropological Records 21. Honolulu : Bishop Museum.

-, 1975. Indigenous food processing in Oceania. In M. Arnott (ed.), Gastronomy: The Anthropology of Food and Food Habits, pp. 147-68. Chicago : Aldine. 